\title{
The overlying influence of underground structure and impermeable surface of the ground on groundwater recharge in residential area construction
}

\author{
Qingyang Zheng ${ }^{1, a}$, Shisong $\mathrm{Qu}^{1{ }^{1, *}}$, Jinchao $\mathrm{Li}^{1, \mathrm{~b}}$, Weiping Wang ${ }^{1, \mathrm{c}}$ \\ Zhengxian Zhang ${ }^{1, d}$ \\ ${ }^{1}$ School of resources and environment, University of Jinan/Shandong groundwater numerical \\ simulation and pollution control engineering technology research center, Jinan 250022, in China. \\ a.zqylys@126.com, *.stu_quss@ujn.edu.cn, b.20152205541@mail.ujn.edu.cn, \\ cwangweipingwwp@126.com, d.ZZXSIN@126.com
}

\begin{abstract}
Key words: sponge city; impervious surface on and below the ground; Karst groundwater recharge Abstract. More population and less land is the main contradiction in the process of urbanization in China. Residential buildings developing upward and downward, such as the underground structure, not only made the impervious surface area increased, increasing more surface runoff, but also the underground impervious area increased, jointly cutting the connection between the rainfall infiltration and groundwater recharge and further reducing groundwater recharge and enhancing the heat island effect of the city. A case study of the construction of Jinan urban district puts forward the concept of underground impervious rate, evaluated effect of underground impervious rate on recharge of karst groundwater, analyzed the relationship between the actual impervious surface rate, calculating impervious surface rate and runoff. The result shows the impervious area after construction is an important factor which causes $93 \%$ of the loss of surface water recharging into karst groundwater compared with before construction. Finally, the concept of construction and development of water ecological community in Jinan was proposed according to the special geographical features and the construction of the pilot project of the sponge city in Jinan.
\end{abstract}

\section{Introduction}

Urbanization is an inevitable outcome of the progress of human society and the development of regional social economy, however, the rapid urbanization has also brought many negative effects. The contradiction of more population and less land is the main feature in China which have great pressure on urbanization. First, urban construction land is limited and the population of the unit area is growing rapidly. Second, with the increasing number of cars owned by residents in the past decades, parking lot below the ground in urban development must be designed, and the basement expended from one floor into two floors or more and the underground area almost occupied the authorized construction land area in addition to fundamental land of the buildings. Third, the changing of form of foundation excavation takes place. In the past, the fundamental construction of building only be excavated under the buildings, other open spaces can be used as green lands, roads and squares. Now the buildings construction take account of underground garage and foundation of building as a whole, the large excavation and pouring reinforced concrete are carried out on the ground. The green lands, roads and squares were mostly built with $1.5-1.8 \mathrm{~m}$ of the refilled soil, the bottom of the green land and road are reinforced concrete of impervious area on the top of garage. In case of rainfall, the impervious area of $65-70 \%$ will form a large amount of surface runoff, even cause the flooding of road, then the amount of rainfall infiltration only feeded soil water of $1.5-1.8 \mathrm{~m}$ below surface for evaportranspiration. Compared with the past residential construction, the hydrological cycle has been more serious damages in the entire region, leading to the current cities facing the four major problems of urban water shortage, flood disaster, heat island effect and water environment pollution[1].Therefore, it is of great significance for China to make a clear understanding of the impact of residential construction on groundwater and take corresponding remedial measures. 


\section{Basic situation of the study area}

Jinan is famous as its springs, but the city's development directly affects the flowing of spring water. According to statistics, the average annual rainfall is $659 \mathrm{~mm}$ and the area of Jinan city increased from $26 \mathrm{~km}^{2}$ in 1949 to $485.3 \mathrm{~km}^{2}$ in 2014 . A large number of new impervious ground, especially resulting from underground engineering constructions, further increase the surface runoff and reduce the recharge of karst water. In addition, natural rivers and gullies system are mainly used as flood discharge in Jinan with urban flood control standard being less than 50 years frequency, and many drainage channels are occupied by buildings which often block flood in rivers and gullies. The flood of road caused by general heavy rain will seriously affect the traffic safety.

The main change is the increase of impervious area in the process of urbanization, which can reduce the amount of infiltration, interception, evaporation, base flow and groundwater stage and increase surface runoff. Kalin et al. (2006) found that when $60 \%$ of the forest land was developed into commercial land and low-density residential land, the base flow of the river basin will be reduced by 31\%[2].Wenming Nie et al. (2001) taken San Pedro River as an example to analyze quantitatively the influence of each kind of land cover changes on the hydrological process[3]. The result shown that the urbanization process has the greatest contribution to the reduction of base flow, infiltration and evaporation, while the increase of runoff, and the reduction of infiltration have negative effects on the water resources of San Pedro River basin. In China, $\mathrm{Na} \mathrm{Li} \mathrm{(2009)} \mathrm{simulated} \mathrm{the} \mathrm{runoff} \mathrm{of} \mathrm{Xitiao} \mathrm{river.}$ They found the increased impermeable surface caused by the expansion of city is one of the main factors to change the regional hydrological effect[4]. Jing Zheng et al. (2010) simulated the hydrological process of Buji River Basin in Shenzhen under the different land use conditions with the SWAT model[5]. They found that the land use in 2005 compared to 1980, the amount of evapotranspiration, soil moisture content and underground runoff of the basin were reduced by $42.09 \mathrm{~mm}, 28.10 \mathrm{~mm}$ and $279.74 \mathrm{~mm}$, and the surface runoff increased $431.97 \mathrm{~mm}$. The change of land use caused by urbanization process has a great influence on the surface runoff, evapotranspiration, soil water content and interannual variability of underground runoff.

In a word, a lot of researches on the effect of increased impervious surface on hydrological cycle have been done, but there are few reports on how to quantitatively analyze and take appropriate measures about the negative influence caused by the increased impervious underground area in the vertical direction.

\section{The impact of building and residential impervious rate and compensation measures on hydrological cycle}

In order to protect the flowing of spring water, the regulation of water and soil conservation of Jinan stipulates that the surface impervious rate of the construction project can not exceed $30 \%$ in the karst groundwater direct recharge area. The item played a certain role in protecting karst water conservation area of the Jinan southern mountain. But in the last ten years, with the increase of land price in southern mountainous areas, there has been a lot of real estate development projects. In order to reduce the construction damage of hydrological cycle in Karst area, according to the soil and water conservation plan of the construction project, the actual impervious surface rate, the calculation of the impervious surface rate and the impervious underground rate are presented in order to evaluate the impervious surface rate and adopt effective measures of rainwater storage, retention, infiltration, slowing down and compensating the increased surface runoff caused by hardening. A constructing area is taken as an example is analyzed. The district is located in the direct recharge area of groundwater in Jinan southern mountainous area. In the locality there is bare limestone or overlying a thin silty clay and the underground karst fractures are well developed, and the surface runoff can penetrate rapidly surface to the underground through the fractured rock to recharge the groundwater. The planning total area of the residential area is $2380 \mathrm{~m}^{2}$, the planning of construction land is $20779 \mathrm{~m}^{2}$, the ground volume rate is 1.1 , the underground volume rate is 0.5 . The total construction area is $33245 \mathrm{~m}^{2}$, of which the floor area above the ground is $22856 \mathrm{~m}^{2}$ (including residential, commercial street), underground 
construction area is $10389 \mathrm{~m}^{2}$ (including underground garage that is the area of equipment rooms). The building, road square and green area areas are $6649 \mathrm{~m}^{2}, 8935 \mathrm{~m}^{2}$ and $5195 \mathrm{~m}^{2}$ respectively, with greening rate of $25 \%$. Impervious underground area is $1.05 \mathrm{hm}^{2}$, the overlying soil on the underground garage to the surface is about $1.2-1.5 \mathrm{~m}$.

Before construction. The surface runoff: the planning of construction land in the project is $2.0779 \mathrm{hm}^{2}$, the runoff coefficient in this area is 0.15 before construction[6].The amount of surface runoff is: $0.15 \times 20779 \mathrm{~m}^{2} \times 659 \mathrm{~mm}=2054 \mathrm{~m}^{3}$

The recharge of underground karst water: the planning of construction land is 2.0779 , the recharge coefficient of rainfall infiltration in the direct recharge area of karst water is 0.29 before construction. The average annual precipitation infiltration to recharge groundwater is:

\section{$0.29 \times 20779 \mathrm{~m}^{2} \times 659 \mathrm{~mm}=3971 \mathrm{~m}^{3}$}

After construction. The impervious surface rate and runoff: the actual impervious surface rate refers to the proportion of the buildings, roads and squares and other impervious area of the total construction area of the district. The planning of construction land in the project is $2.0779 \mathrm{hm}^{2}$, of which, the building impervious area is $0.67 \mathrm{hm}^{2}$, and the road square impervious area is $0.89 \mathrm{hm}^{2}$, therefore, the total impervious area of the project is $1.56 \mathrm{hm}^{2}$, the impervious rate is $75 \%$. After hardening, the runoff coefficient was 0.85 , without any compensations, the surface runoff after construction was: $0.15 \times 5195 \mathrm{~m}^{2} \times 659 \mathrm{~mm}+0.85 \times\left(6649 \mathrm{~m}^{2}+8935 \mathrm{~m}^{2}\right) \times 659 \mathrm{~mm}=9242.90 \mathrm{~m}^{3}$

The impervious underground rate and rainfall infiltration recharge of karst water: the impervious rate refers to the proportion of underground engineering such as garage and storage area of the total construction area. The construction land in the project is $2.38 \mathrm{hm}^{2}$, in which, the underground building area is $1.05 \mathrm{hm}^{2}$, so the impervious underground rate is $51 \%$.

After construction, the greening rate was $25 \%$, the impervious underground rate was $51 \%$. The preliminary design data shown that the overlapping area of the green area and the underground garage area is $18 \%$ of the green area. Only $7 \%$ green area receive rainfall infiltration to recharge groundwater, the groundwater recharge was: $0.29 \times 20779 \mathrm{~m}^{2} \times 0.07 \times 659 \mathrm{~mm}=278 \mathrm{~m}^{3}$

Therefore, after construction the rainfall infiltration recharge of groundwater decreased by $93 \%$ compared with before construction.

From the vertical perspective, the large underground impervious rate will hinder the infiltration of rainfall and surface water, jointly cutting the hydraulic connection between surface and groundwater during the wet season. The depth of covering soil in the impervious ground area is shallower, which reduces the soil water storage. In order to meet the surface plant evapotranspiration, the amount of irrigation water need to add. From the horizontal perspective, excessive depth of impervious underground foundation engineering will change the flow field of underground runoff and destroy the underground ecosystem.

Analysis of surface runoff compensation after taking rainwater utilization measures. It is possible to compensate the negative influence caused by the impervious surface rate through taking measures such as rainwater storage, infiltration, irrigation and so on. The rainwater runoff produced by hardening is directed into the soil or groundwater, which indirectly reduces the partial impervious area.

Reduced the impervious rate of the project by taking following measures:

The roof area of building area is $0.67 \mathrm{hm}^{2}$. After taking the roof rainwater collection measures, about $90 \%$ of rainwater are stored (in addition to $5 \%$ of the roof interception and the initial removal of 5\% ), the effective utilization rate is up to $85 \%$, the infiltration area was:

$$
F_{\text {infiltration }}=0.67 \mathrm{hm}^{2} \times 0.9 \times 0.85=0.51 \mathrm{hm}^{2}
$$

Pervious concrete are applied to roads and squares of the area about $0.48 \mathrm{hm}^{2}$, the runoff coefficient of about $60 \%$ and the infiltration rate of $40 \%$. The infiltration area was:

$$
F_{\text {infiltration }}=0.48 \mathrm{hm}^{2} \times 0.40=0.20 \mathrm{hm}^{2}
$$


Permeable brick can be used to promote infiltration is about $0.36 \mathrm{hm}^{2}$, the runoff coefficient of about $35 \%$ and the infiltration rate of $65 \%$. The infiltration area was:

$$
\mathrm{F}_{\text {infiltration }}=0.36 \mathrm{hm}^{2} \times 0.65=0.24 \mathrm{hm}^{2}
$$

When the water conservation measures recommended by the scheme are adopted in the project area, the impermeable area was reduced by $0.95 \mathrm{hm}^{2}$, the impervious area was reduced from the previous actual of $1.56 \mathrm{hm}^{2}$ to the calculated of $0.61 \mathrm{hm}^{2}$, the impervious rate was decreased from $75 \%$ before governance to $29 \%$ after measured. All indexes met the requirements.

After taking the compensation, the surface runoff was:

$$
0.15 \times 14679 \mathrm{~m}^{2} \times 659 \mathrm{~mm}+0.85 \times 6100 \mathrm{~m}^{2} \times 659 \mathrm{~mm}=4867.93 \mathrm{~m}^{3}
$$

The surface runoff was reduced by $4374.97 \mathrm{~m}^{3}$, and the reduction rate was $47 \%$.

Comparison of infiltration amount before and after construction. The construction land in the project is $2.0779 \mathrm{hm}^{2}$, the infiltration rate of the area is $85 \%$. After hardening, the infiltration rate was $15 \%$.

Before construction infiltration is: $0.85 \times 20779 \mathrm{~m}^{2} \times 659 \mathrm{~mm}=11639.36 \mathrm{~m}^{3}$

Without any compensations, the infiltration after construction is:

$$
0.85 \times 5195 \mathrm{~m}^{2} \times 659 \mathrm{~mm}+0.15 \times\left(6649 \mathrm{~m}^{2}+8935 \mathrm{~m}^{2}\right) \times 659 \mathrm{~mm}=4450.46 \mathrm{~m}^{3}
$$

Under the conditions of compensation, the infiltration after construction is:

$$
0.85 \times 14679 \mathrm{~m}^{2} \times 659 \mathrm{~mm}+0.15 \times 6100 \mathrm{~m}^{2} \times 659 \mathrm{~mm}=8825.43 \mathrm{~m}^{3}
$$

Without any compensations, the infiltration of the area was decreased from $11639.36 \mathrm{~m}^{3}$ to $4450.46 \mathrm{~m}^{3}$ before and after construction. After taking measures, the surface runoff was decreased and the infiltration was reduced to $8825.43 \mathrm{~m}^{3}$, but there is no fundamental solution to the permanent loss of the karst water supply due to the new underground structures destroyed the channel of vertical infiltration and recharge of groundwater.

\section{Countermeasures}

Jinan urban construction should seize the opportunity to build water ecological civilization city and sponge city pilot project, by taking effective compensation measures to reduce the negative impact of urban construction on the hydrological cycle factor[6].

On the small scale, the measures of storage, retention, infiltration and so on can utilize the rainwater runoff produced by the impervious surface in the region as far as possible. It not only can reduce the pressure of flood control but also increase the capacity of rainwater storage.

At the regional scale, Jinan urban construction should base on the characteristics of the mountain and valley plain with higher permeability to establish a buffer zone to communicate with surface water and groundwater. In the low-lying area, Jinan should detain flood and promote infiltration as far as possible. In the high-lying areas, Jinan should take measures to extend the runoff formation time as much as possible, in order to reach the runoff peak and turn harm into good.

\section{Acknowledgment}

The project is funded by Water Ecological Civilization Scientific Program of Shandong Water Resource Bureau and Finance Bureau (SSTWMZCLH-SD06; JNQY-SZY-GC-2016-001).

\section{References}

[1]Weiping Wang, Shisong Qu, Xinqiang Ye, et al., in:Study on the water quality characteristics of roof rainwater runoff in karst aquifer[J], in Chinese, edited by Journal of Hydraulic Engineering, 2011, 42(4):477-482. 
[2]Kalin, Latif, Hantush, Mohamed M, in: Hydrologic modeling of an eastern Pennsylvania watershed with NEXRAD and rain gauge data[J], edited by Journal of Hydraulic Engineering, 2006,11(6):555-569.

[3] Wenming Nie, Yongping Yuan, William Kepner, in: Assessing impacts of land use and landcover changes on hydrology for the upper San Pedro watershed[J], edited by Journal of Hydrology, 2011,407(1-4):105-114.

[4] Na Li, Youpeng Xu, Huaicheng Guo, in: Based on the long-term runoff analysis and research of the influence of Xitiao River City[J], in Chinese, edited by Journal of Peking University (natural science edition), 2009,45(4):668-676.

[5] Jing Zheng, Weihua Fang, Peijun Shi, et al., in: A simulation study on the effects of land use change on hydrological processes in a fast urbanization area-A case study of Buji River Basin in Shenzhen[J], in Chinese, edited by Journal of Natural Resources,2009,24(9):1560-1572.

[6]Yong Xu, Tengyun Guo, in: Land use process and driving forces analysis of Loess Hilly Region[J],in Chinese, edited by Soil and Water Conservation Research, 2006, 13(2):1-3. 